\title{
Pichia opuntiae, a New Heterothallic Species of Yeast Found in Decaying Cladodes of Opuntia inermis and in Necrotic Tissue of Cereoid Cacti
}

\author{
W. T. STARMER, $\dagger$ H. J. PHAFF, MARY MIRANDA, M. W. MILLER, AND J. S. F. BARKER $\ddagger$ \\ Department of Food Science and Technology, University of California, Davis, California 95616
}

A new heterothallic species of Pichia has been recovered 25 times from widely separated cactus substrates. The organism has been named Pichia opuntiae because the sexually most compatible strains were isolated from Opuntia inermis in Australia. Two varieties are designated based on differences in physiology, habitat, and geographic distribution. $P$. opuntiae var. opuntiae has a maximum temperature for growth of 30 to $33^{\circ} \mathrm{C}$ and assimilates citric acid strongly, but assimilation of cellobiose is latent, weak, or negative. $P$. opuntiae var. thermotolerans grows well at $37^{\circ} \mathrm{C}$, but not at $39^{\circ} \mathrm{C}$; it assimilates cellobiose strongly but does not assimilate citric acid. Ecologically, $P$. opuntiae var. opuntiae is associated with Opuntia inermis (tribe Opuntiaeae, subtribe Opuntiinae) in Australia; $P$. opuntiae var. thermotolerans is associated with species of the cactus tribe Pachycereeae, subtribe Pachycereinae, from various locations in the North American Sonoran Desert. A discussion of the physiological and host-plant shifts for these two varieties and three similar cactophilic yeasts is presented. The base composition of the nuclear deoxyribonucleic acid of $P$. opuntiae var. opuntiae (average of four strains) is $33.64 \pm 0.25 \mathrm{~mol} \%$ guanine plus cytosine and that of $P$. opuntiae var. thermotolerans (average of 3 strains) is $33.13 \pm 0.23 \mathrm{~mol} \%$ guanine plus cytosine. The type strain of $P$. opuntiae and of the type variety, $P$. opuntiae var. opuntiae, is UCD-FS\&T 77-40 (= ATCC $36836=$ CBS 7010). The type strain of $P$. opuntiae var. thermotolerans is UCD-FS\&T 76-211 (= ATCC $36834=$ CBS 7012).

In the course of an extensive survey of cactusinhabiting yeasts in Baja California and Sonora, Mexico, we encountered seven asporogenous strains physiologically similar to Pichia quercuum Phaff et Knapp or to the imperfect yeast Candida norvegensis (Dietrichson) van Uden et Farinha ex van Uden et Buckley. These isolates were all from cereoid cacti sampled in the North American Sonoran Desert. On extending the survey of cactus habitats to include decaying cladodes of Opuntia inermis de Candolle from Australia, we found a number of strains closely resembling the isolates from cereoid cacti.

The survey of cactus habitats in the North American Sonoran Desert was initiated as a part of a study of the genetics and ecology of cactophilic Drosophila, i.e., D. pachea Patterson and Wheeler, $D$. nigrospiracula Patterson and Wheeler, D. mettleri Heed, and D. mojavensis Patterson and Crow $(6,14)$. The survey of cactus habitats in Australia is being done as part of a study of the genetics and ecology of the cacto-

† Present address: Department of Biology, Syracuse University, Syracuse, NY 13210.

$\ddagger$ Department of Animal Husbandry, University of Sydney, New South Wales 2006, Australia. philic drosophilae in Australia, namely, $D$. buzzatii Patterson and Wheeler and D. aldrichi Patterson and Crow $(1,2,9)$.

The strains recovered from Opuntia necroses represented haploid mating types which conjugated well among one another but somewhat less vigorously with the isolates from cereoid cacti. A study of the guanine plus cytosine $(\mathrm{G}+\mathrm{C})$ content of the nuclear deoxyribonucleic acids (DNAs) of representative strains established the cactus isolates to be distinctly different from Pichia quercuum and C. norvegensis. The cactus isolates displayed an average $\mathrm{G}+\mathrm{C}$ content of $33.4 \mathrm{~mol} \%$ (seven strains), whereas $P$. quercuum DNA had $40 \mathrm{~mol} \% \mathrm{G}+\mathrm{C}(10)$, and $C$. norvegensis DNA had 35.5 to $36.0 \mathrm{~mol} \% \mathrm{G}+\mathrm{C}$ (8). The following observations constitute convincing evidence for regarding the cactus isolates as representatives of two varieties of a new species in the genus Pichia: (i) their physiology, (ii) sexual interfertility, (iii) comparable $\mathrm{G}+\mathrm{C}$ contents of the nuclear DNAs, (iv) the ecological association with decaying cacti, and (v) formation of hat-shaped ascospores in diploid cells originating from zygotes.

We have named this species Pichia opuntiae 
on the basis of its recovery from necroses of $O$. inermis. Moreover, we have established two varieties based on consistent physiological differences which correlate with the habitat specificity and geographic origins of the strains.

Strains recovered from the decaying stems of $O$. inermis sampled in Australia are designated $P$. opuntiae var. opuntiae, whereas those strains isolated from cereoid cacti of the subtribe $\mathrm{Pa}$ chycereinae in the North American Sonoran Desert are designated $P$. opuntiae var. thermotolerans.

\section{MATERIALS AND METHODS}

Samples of necrotic cactus tissue were collected from four areas of the North American Sonoran Desert (Fig. 1). These collections were part of an extensive survey of this region carried out in March 1976. Several new cactus-specific species of Pichia from this area have been reported $(11,15,16)$. Additional samples were collected in Australia from decaying cladodes of $O$. inermis at Yarrawonga (latitude $32^{\circ} 30^{\prime} \mathrm{S}$; longitude, $\left.150^{\circ} 36^{\prime} \mathrm{E}\right)$ and at Martindale $(7.5 \mathrm{~km} \mathrm{NE}$ of Yarrawonga) during 1976 and 1977. The localities and sources of the isolates are listed in Table 1.

Most of the isolations were accomplished by streaking a loopful of necrotic tissue directly on acidified yeast extract-malt extract agar (Difco YM agar + $0.7 \%$ [vol/vol] $1 \mathrm{~N} \mathrm{HCl}=\mathrm{AYM}, \mathrm{pH} 3.7$ to 3.8) in the field. In some cases, dilutions of the tissue were made in sterile water as described earlier (14). The plates were

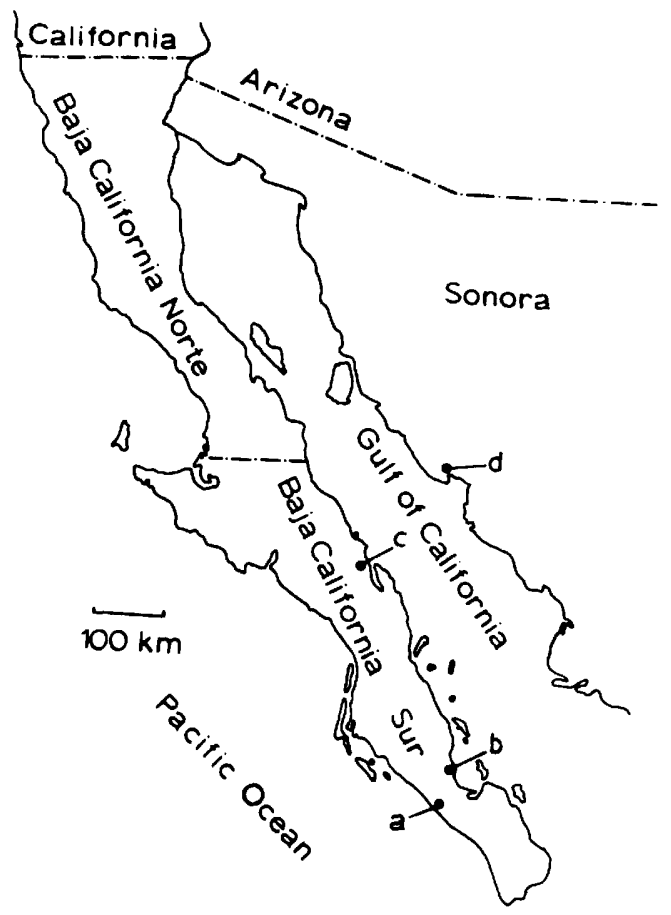

FIG. 1. Collection localities in Mexico for isolates of P. opuntiae var. thermotolerans listed in Table 1. stored at ambient temperatures $\left(24\right.$ to $\left.30^{\circ} \mathrm{C}\right)$ until colonies appeared. Counts of morphologically distinct colony types were then made, and for identification a representative of each type was brought into pure culture by two successive platings on YM agar.

Identification was done by standard methods currently used in yeast taxonomy (18). DNA extraction and purification were done by a combination of the procedures of Marmur (7) and Bernardi et al. (3) as described by Price et al. (12). The G+C content of the DNA was calculated from buoyant density values in cesium chloride $(13,17)$ and was based on two or three separate determinations. Micrococcus lysodeikticus strain 2039 (International Collection of Phytopathogenic Bacteria, Department of Bacteriology, University of California, Davis) DNA, with a buoyant density of $1.7311 \mathrm{~g} / \mathrm{ml}$, was used as a reference. The buoyant density of the $M$. lysodeikticus DNA was derived from comparison with plasmid-free Escherichia coli $\mathrm{K}-12$ DNA, the buoyant density of which was taken to be $1.7100 \mathrm{~g} / \mathrm{ml}$.

Single ascospores were isolated from mature asci with a micro-manipulator (4) and sometimes after treatment of the sporulating suspension of cells and asci with the cell wall-digesting enzyme Zymolyase.

\section{RESULTS}

Latin diagnosis of $P$. opuntiae sp. nov. Pichia opuntiae var. opuntiae var. nov. In extracto malti cellulae ovoideae, vel elongatae, 2.2$4.9 \times 3.2-8.1 \mu \mathrm{m}$, singulae, binae, in catenis brevis; annulus et pellicula tenuis, non-nitida.

Cultura in agaro malti post unum mensem $\left(25^{\circ} \mathrm{C}\right)$ cana vel alutacea, butyrosa vel mollis, plana, glabra cum lineis radiatis, patula, nitida vel semi-nitida; margine glabro vel undulato.

In agaro farinae Zea mays post dies 10, pseudomycelium nullum vel rudimentarius. Species heterothallica haploidea aut raro diploidea. Asci ex cellulae diploidae inconjuganti fiunt, habentes 2, 3 aut interdum, 4 sporas pileiformae; asci rumpunter post 4-5 dies.

Fermentatio glucosi nullum.

Glucosum, cellobiosum (lente, exigue, vel nullum), rhamnosum (lente), ethanolum, glycerolum, mannitolum (lente, exigue, vel nullum), salicinum, acidum lacticum, acidum succinicum, et acidum citricum (valde) assimilantur at non galactosum, L-sorbosum, maltosum, saccharum, trehalosum, lactosum, melibiosum, raffinosum, melezitosum, inulinum, amylum solubile, D-xylosum, L-arabinosum, D-arabinosum, D-ribosum, methanolum, erythritolum, ribitolum, galactitolum, D-glucitolum, $\alpha$-methyl-D-glucosidum, 2 - et 5-ketogluconatum, D-glucosaminum, nec inositolum.

Kalium nitricum et natrium nitrosum non assimilantur.

Ethyl aminum assimilatur.

Ad crescentiam biotinum, pyridoxinum et thiaminum necessariae sunt. 
TABLE 1. Localities and sources for isolates of $P$. opuntiae used in this study

\begin{tabular}{|c|c|c|c|c|}
\hline Variety & Serial no. & UCD-FS\&T no. & Localitya & Habitat \\
\hline \multirow[t]{2}{*}{$\begin{array}{l}\text { P. opuntiae var. } \\
\text { opuntiae }\end{array}$} & $\begin{array}{c}1,2,3,4,5,6 \\
7,8,9,10 \\
11,12,13 \\
14,15,16\end{array}$ & $\begin{array}{c}77-37,77-40,77-42,77- \\
45,77-154,77-155 \\
77-177,77-201,77- \\
202 B, 77-205,77-206 \\
77-231,77-280,78- \\
199,78-303 B, 78-304\end{array}$ & $\begin{array}{l}\text { Yarrawonga, Australia } \\
\text { (170 km NNW of Sydney) }\end{array}$ & $\begin{array}{l}\text { O. inermis } \\
\text { de Candolle }\end{array}$ \\
\hline & 17,18 & $77-159,77-162$ & $\begin{array}{l}\text { Martindale, Australia } \\
\text { (7.5 km NE of Yarrawonga) }\end{array}$ & O. inermis \\
\hline \multirow[t]{6}{*}{$\begin{array}{l}\text { P. opuntiae var. } \\
\text { thermotolerans }\end{array}$} & 19 & $76-211$ & $\begin{array}{l}\text { Rancho Cuñaño, Baja } \\
\text { California Sur, } \\
\text { Mexico (a) }\end{array}$ & $\begin{array}{l}\text { L. schottii } \\
\text { (Engelm.) } \\
\text { Britt. et } \\
\text { Rose [senita] }\end{array}$ \\
\hline & 20 & $76-288$ & $\begin{array}{l}\text { North of La Paz, } \\
\text { Baja California Sur, } \\
\text { Mexico (b) }\end{array}$ & $\begin{array}{l}\text { L. schottii (Engelm.) } \\
\text { Britt. et } \\
\text { Rose [senita] }\end{array}$ \\
\hline & 21,22 & $76-330,76-333 B$ & $\begin{array}{l}\text { Mulegé, Baja } \\
\text { California Sur, } \\
\text { Mexico (c) }\end{array}$ & $\begin{array}{l}\text { Pachycereus pringlet } \\
\text { (S. Wats.) } \\
\text { Britt. et Rose } \\
\text { [cardon] }\end{array}$ \\
\hline & 23 & $76-385 B$ & $\begin{array}{l}\text { Mulegé, Baja } \\
\text { California Sur, } \\
\text { Mexico (c) }\end{array}$ & $\begin{array}{l}\text { Moist soil under } \\
P \text {. pringlei } \\
\text { [cardon] }\end{array}$ \\
\hline & 24 & $76-411$ & $\begin{array}{l}\text { Guaymas, Sonora, } \\
\text { Mexico (d) }\end{array}$ & $\begin{array}{l}P . \text { pringlei } \\
\text { [cardon] }\end{array}$ \\
\hline & 25 & $76-412 B$ & $\begin{array}{l}\text { Guaymas, Sonora, } \\
\text { Mexico (d) }\end{array}$ & $\begin{array}{l}\text { P. pectenaboriginum } \\
\text { (Engelm.) } \\
\text { Britt. et Rose } \\
\text { [hecho] }\end{array}$ \\
\hline
\end{tabular}

\footnotetext{
${ }^{a}$ Letters in parentheses indicate the map localities depicted in Fig. 1.
}

${ }^{\circ}$ Common names of cacti are given in brackets.

Crescere potest in $30^{\circ} \mathrm{C}$, interdum in $33^{\circ} \mathrm{C}$.

$\mathrm{G}+\mathrm{C}$ acidi deoxyribonucleati $=33.44-33.98$ mol\% (4 stirpes, vide tabulum 2).

Habitatio in cactis.

Typus: Stirps UCD (FS\&T) 77-40 ex tabidosus sacculis cacti Opuntia inermis isolata est.

In collectione zymotica Centraalbureau voor Schimmelcultures, Delphi Batavorum sub no. 7010 deposita est.

Cultura auxiliaris UCD (FS\&T) 77-42 (= CBS 7011) sexus alterius.

Pichia opuntiae var. thermotolerans var. nov. Varietas a $P$. opuntiae var. opuntiae differt: cellobiosum assimilatur valde, D-mannitolum assimilatur lente sed valde, at non acidum citricum; crescere potest in $37^{\circ} \mathrm{C}$; $\mathrm{G}+\mathrm{C}$ acidi deoxyribonucleati $=32.88-33.33 \mathrm{~mol} \%$ (3 stirpes, vide tabulum 2). Habitatio in cactis subtribus Pachycereinae.

Typus: Stirps UCD (FS\&T) 76-211 ex tabidosus sacculis cacti Lophocereus schottii isolata est.

In collectione zymotica Centraalbureau voor Schimmelcultures, Delphi Batavorum sub no. 7012 deposita est.

Cultura auxiliaris UCD (FS\&T) 76-385B (= CBS 7013) sexus alterius.

Standard description of Pichia opuntiae sp. nov. (i) Pichia opuntiae var. opuntiae var. nov. Growth in malt extract: after 3 days at $25^{\circ} \mathrm{C}$ the cells are ovoid to slightly elongate, 2.2 to 4.9 by 3.2 to $8.1 \mu \mathrm{m}$. The thallus consists of single cells, pairs, short chains, and clusters that can be rather large, consisting of extensively branched chains. A ring and a thin, dull pellicle are formed. Little sediment is formed.

Growth on malt agar: after 1 month at $25^{\circ} \mathrm{C}$, the streak culture is grayish to tan, butyrous to soft, flat with a central ridge, smooth with slight radial striations, spreading, and glossy to semiglossy; the border is entire to lobulate.

Dalmau plate culture on cornmeal agar: pseudomycelium absent or rudimentary, consisting of irregular clusters in the anaerobic area under the cover glass.

Formation of ascospores: the vegetative cells are heterothallic, usually occurring in the haploid state when isolated from nature. Conjugation and sporulation are best observed on Difco $\mathrm{YM}$ agar at $25^{\circ} \mathrm{C}, 3$ to 5 days after the appropriate mating types have been mixed together. Ascospores are usually formed in diploid cells that bud from the zygotes (Fig. 2). The spores are hat shaped and usually occur in pairs, although asci may contain three or rarely four spores. Asci containing four spores have been dissected yielding two spores of one mating type and two of the opposite mating type. The asci dehisce rapidly, releasing the spores immediately after formation. 
TABLE 2. Mating types, ability to assimilate cellobiose, maximum temperatures for growth, and nuclear DNA base compositions of representative strains of $P$. opuntiae

\begin{tabular}{|c|c|c|c|c|c|c|}
\hline \multirow{2}{*}{ Variety } & \multirow{2}{*}{ Strain no. } & \multirow{2}{*}{$\begin{array}{l}\text { Assimilation } \\
\text { of cellobiose }\end{array}$} & \multirow{2}{*}{$\begin{array}{c}\text { Mating } \\
\text { type }^{a}\end{array}$} & \multicolumn{2}{|c|}{ Growth at: } & \multirow{2}{*}{$\begin{array}{c}\mathrm{G}+\mathrm{C} \pm \mathrm{SD}^{c} \\
(\mathrm{~mol} \%)\end{array}$} \\
\hline & & & & $33^{\circ} \mathrm{C}^{b}$ & $37^{\circ} \mathrm{C}$ & \\
\hline \multirow{18}{*}{$\begin{array}{l}\text { P. opuntiae var. } \\
\text { opuntiae }\end{array}$} & 1 & Latent & $\mathrm{h}^{+}$ & + & - & $33.65 \pm 0.08$ \\
\hline & 2 & Latent & $\mathrm{h}^{+}$ & + & - & $33.98 \pm 0.04$ \\
\hline & 3 & - & $\mathbf{h}^{-}$ & + & - & $33.48 \pm 0.10$ \\
\hline & 4 & Latent & $\mathbf{h}^{+}$ & + & $\cdot-$ & \\
\hline & 5 & - & Diploid & + & - & $33.44 \pm 0.13$ \\
\hline & 6 & Weak & Diploid & + & - & \\
\hline & 7 & - & $\mathrm{h}^{-}$ & + & - & \\
\hline & 8 & - & $\mathbf{h}^{-}$ & + & - & \\
\hline & 9 & - & $\mathbf{h}^{-}$ & + & - & \\
\hline & 10 & Latent & $\mathbf{h}^{+}$ & + & - & \\
\hline & 11 & - & $\mathbf{h}^{-}$ & + & - & \\
\hline & 12 & - & $\mathrm{h}^{+}$ & + & - & \\
\hline & 13 & - & $\mathbf{h}^{-}$ & + & - & \\
\hline & 14 & Latent & $\mathbf{h}^{+}$ & + & - & \\
\hline & 15 & Weak & $\mathbf{h}^{+}$ & - & - & \\
\hline & 16 & Latent & $\mathbf{h}^{+}$ & - & - & \\
\hline & 17 & Latent & $\mathbf{h}^{-}$ & - & - & \\
\hline & 18 & Latent & $\mathrm{h}^{+}$ & - & - & \\
\hline \multirow{6}{*}{$\begin{array}{l}P . \text { opuntiae var. } \\
\text { thermotolerans }\end{array}$} & 19 & + & $\mathbf{h}^{+}$ & + & + & $33.33 \pm 0.02$ \\
\hline & 20 & + & $\mathbf{h}^{-}$ & + & + & \\
\hline & 21,22 & + & $\mathbf{h}^{-}$ & + & + & \\
\hline & 23 & + & $\mathbf{h}^{-}$ & + & + & $33.19 \pm 0.18$ \\
\hline & 24 & + & $\mathbf{h}^{+}$ & + & + & \\
\hline & 25 & + & $\mathbf{h}^{+}$ & + & + & $32.88 \pm 0.16$ \\
\hline
\end{tabular}

${ }^{a} \mathrm{~h}^{+}$and $\mathrm{h}^{-}$designate haploid strains of opposite mating type.

${ }^{b}$ All strains grew well at $30^{\circ} \mathrm{C}$.

' The values for strains 1,3 , and 19 were based on two separate determinations; the values for strains $2,6,23$, and 25 were based on three determinations.

Other characteristics: Ability to ferment glucose is absent. Assimilation of carbon compounds: D-glucose, cellobiose (latent, weak, or negative), rhamnose (latent or weak), ethanol, glycerol, mannitol (latent, weak, or negative), salicin, DL-lactic acid, succinic acid, and citric acid (strong) are assimilated. The following compounds are not assimilated: D-galactose, L-sorbose, maltose, sucrose, trehalose, lactose, melibiose, raffinose, melezitose, inulin, soluble starch, D-xylose, L-arabinose, D-arabinose, D-ribose, methanol, erythritol, ribitol, galactitol, Dglucitol, $\alpha$-methyl-D-glucoside, 2- and 5-ketogluconate, D-glucosamine, and meso-inositol.

Assimilation of nitrogen compounds: potassium nitrate, negative; sodium nitrite, negative; ethylamine, positive; ammonium sulfate, positive.

Growth in vitamin-free medium: absent. Pyridoxine and thiamine are required for growth. Biotin is stimulatory.

Growth in amino acid free medium: positive.

Growth on $50 \%$ (wt/wt) glucose yeast extract agar: negative.

Growth on osmotic salt agar: on $5 \% \mathrm{NaCl}$ plus $5 \%$ glucose-yeast extract agar, positive; on $7.5 \%$
$\mathrm{NaCl}$ plus $5 \%$ glucose-yeast extract agar, negative.

Maximum temperature for growth: 30 to $33^{\circ} \mathrm{C}$, depending on the strain.

Acid formation on chalk agar: negative, occasionally weak.

Hydrolysis of urea: negative.

Gelatin liquefaction: negative.

Casein hydrolysis: negative.

Lipolytic activity: negative.

Growth in the presence of $0.1 \mathrm{mg}$ of cycloheximide per ml: negative.

$\mathrm{G}+\mathrm{C}$ content of the nuclear DNA: 33.44 to $33.98 \mathrm{~mol} \%$ (four strains, Table 2).

Habitat: Eighteen strains were recovered in New South Wales, Australia, from necrotic tissue of $O$. inermis in the cactus tribe Opuntiaeae.

Type: The type strain of $P$. opuntiae var. opuntiae, UCD (FS\&T) 77-40, was isolated from a rot of $O$. inermis at Yarrawonga, Australia. The auxiliary strain giving best sporulation with 77-40, UCD (FS\&T) 77-42, was isolated 1 month earlier from a different rot at the same locality. The two strains, $77-40$ and $77-42$, have been deposited in the collection of the Yeast Division of the Centraalbureau voor Schimmelcultures in 

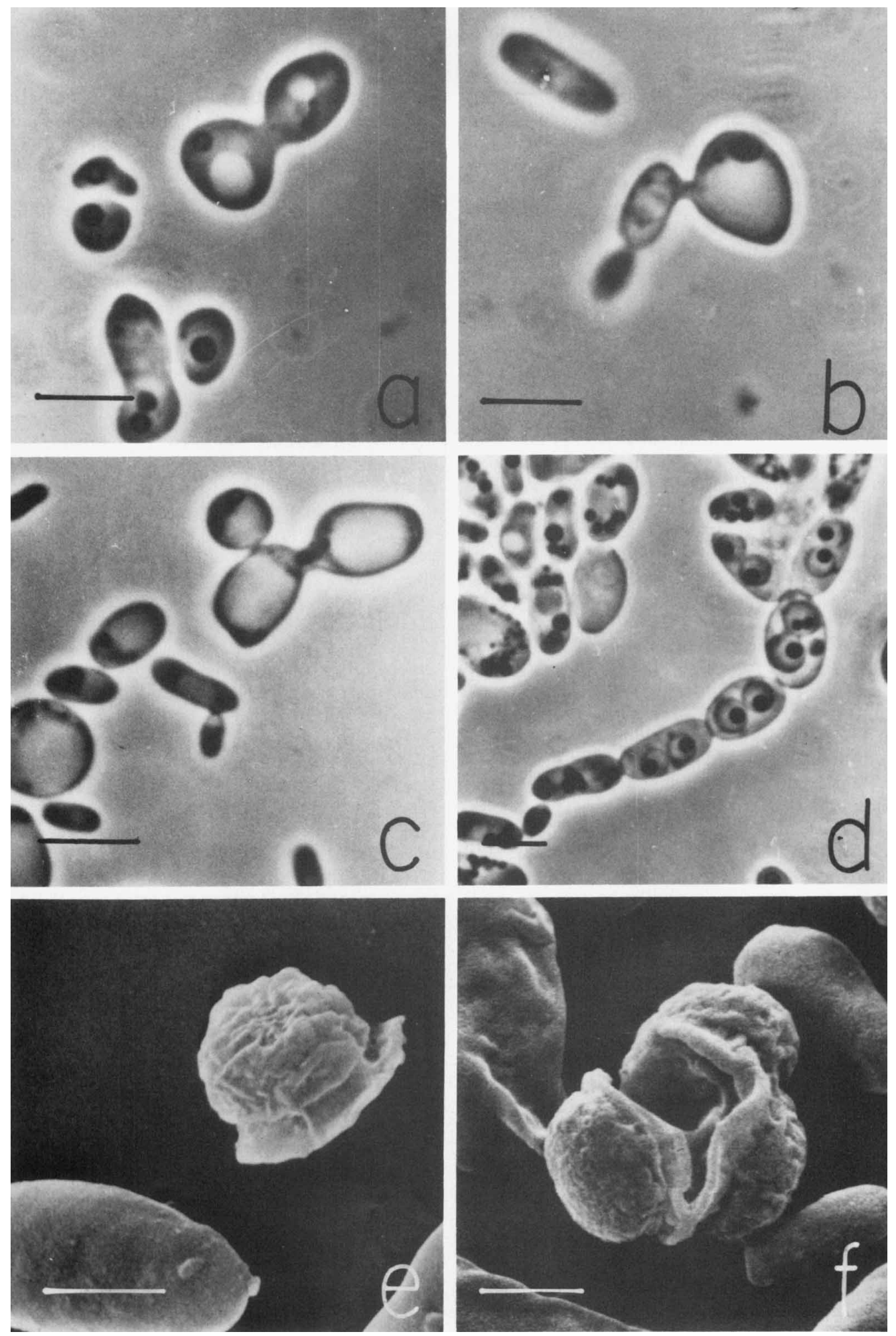

FIG. 2. Various stages in the sexual reproduction of Pichia opuntiae var. opuntiae. (a) Zygote formed $24 h$ after mixing compatible mating types on YM agar; (b) and (c) diploid cell budding from zygotes; (d) a chain of diploid asci, each containing two hat- to helmet-shaped ascospores (after 4 to 5 days) (note the conspicuous lipid globules in the spores); (e) and ( $f$ scanning electron microscope photomicrographs of dehisced ascospores (note the narrow brim on the spores). (a) through (d), bar represents $5 \mu m$; (e) and (f), bar represents $2 \mu m$. 
Delft, The Netherlands as CBS 7010 and 7011, respectively, and in the American Type Culture Collection, Rockville, Md., as ATCC 36836 and 36837 , respectively.

Etymology: opuntiae M.L. f. gen. of opuntia, i.e., pertaining to the organism's association with the cactus Opuntia.

Pichia opuntiae var. thermotolerans. Assimilation of cellobiose: strong. Assimilation of D-mannitol is somewhat latent ( 7 to 10 days) but strong; citric acid is not assimilated. Growth at $37^{\circ} \mathrm{C}$ : positive; growth at $39^{\circ} \mathrm{C}$ : negative.

$\mathrm{G}+\mathrm{C}$ content of the nuclear DNA is 32.88 to $33.33 \mathrm{~mol} \%$ (three strains, Table 2).

Habitat: Five strains were recovered from Baja California Sur and two strains were recovered from the State of Sonora, Mexico, from necrotic tissues of various cacti in the tribe $\mathrm{Pa}$ chycereeae, subtribe Pachycereinae.

Type: The type strain, UCD (FS\&T) 76-211, was isolated from Lophocereus schottii (senita) near Rancho Cuñaño, Baja California Sur, Mexico. The auxiliary strain of complementary mating type, UCD (FS\&T) 76-385B, was isolated from soil moistened by drippings of a rot of the cactus Pachycereus pringlei (cardon) growing near Mulegé, Baja California Sur, Mexico. These strains have been deposited in the collection of the Yeast Division of the Centraalbureau voor Schimmelcultures in Delft, The Netherlands, as CBS 7012 and 7013, respectively, and in the American Type Culture Collection, Rockville, Md., as ATCC 36834 and 36835 , respectively.

Etymology: L. noun thermo, heat; L. adj. tolerans, tolerant; $L$. adj. thermotolerans, referring to the organism's ability to tolerate high temperatures.

\section{DISCUSSION}

Earlier during our work on cactus-inhabiting yeasts in the Sonoran Desert, we considered $P$. opuntiae as an asporogenous strain of $P$. quercuum. All of these isolates were from cacti in the subtribe Pachycereinae, and initially ascospore formation was not observed even when the different strains were mixed in various combinations. Upon obtaining isolates from decaying opuntia cacti from Australia, highly fertile mating types of $P$. opuntiae were discovered. A reinvestigation of the Mexican strains revealed that conjugation among strains of $P$. opuntiae var. thermotolerans is infrequent, and asci are therefore extremely rare. Mixes of opposite mating types of $P$. opuntiae var. opuntiae produce abundant zygotes and numerous asci (Fig. 2). Strains 5 and 6 are self-sporulating heterothallic diploids.

Intervarietal matings produce a moderate number of zygotes but very few asci. Sporulation for intra- and intervarietal crosses can be summarized as follows: $P$. opuntiae var. opuntiae $\times$ $P$. opuntiae var. opuntiae $>P$. opuntiae var. opuntiae $\times P$. opuntiae var. thermotolerans $>$ $P$. opuntiae var. thermotolerans $\times P$. opuntiae var. thermotolerans.

It appears from these observations that $P$. opuntiae var. thermotolerans is adapted to an asporogenous haplophase existence. Whether its low fertility is the result of an adaptation to a different cactus habitat or to the hotter climate of the Sonoran Desert, where P. opuntiae var. thermotolerans is found, is not known. The reason for the somewhat higher mating frequency (zygote formation) between $P$. opuntiae var. opuntiae and $P$. opuntiae var. thermotolerans than between strains of the latter variety may be the high mating capacity of the former variety. In neither cross were sufficient asci present to determine spore viability. It is noteworthy that among other yeasts found in the Sonoran Desert, most sporogenous forms occur primarily as diploids (i.e., Pichia cactophila Starmer et al. [15], Pichia heedii Phaff et al. [11], and Pichia amethionina Starmer et al. [16]), although $P$. amethionina has been isolated in the haploid form.

The lower ability of $P$. opuntiae var. opuntiae to tolerate high temperatures is reflected in its seasonal distribution at Yarrawonga. From October 1976 to November 1977, samples were taken each month from rotting cladodes, and a total of 376 yeast isolates were obtained from 279 rots. Frequencies of $P$. opuntiae var. opuntiae within each season were: spring (September, October, November), 0.09; summer (December, January, February), 0.0; autumn (March, April, May), 0.02; and winter (June, July, August), 0.05 . The self-sporulating diploid strains $(5$ and 6) were collected in July. At Martindale, 20 yeast isolates were obtained from 14 rots from June to September 1977, and the two strains of $P$. opuntiae var. opuntiae (Table 1) were recovered in July.

Recent investigations on the ecological factors important in determining the distribution of the cactus-inhabiting yeasts have revealed that certain cacti contain compounds which are inhibitory to some strains of yeast (W. T. Starmer, unpublished data). In this regard, the two varieties of $P$. opuntiae show a differential response on a complete medium (YNB [Difco] + glucose) supplemented with dry cactus powder. Table 3 shows that $P$. opuntiae var. opuntiae strains are susceptible to medium containing 1\% (dry weight basis) Stenocereus alamosensis (Coulter) Gibson and Horak (5) (cina) powder, 
whereas $P$. opuntiae var. thermotolerans shows no sensitivity to the supplemented medium. The cactus species $S$. alamosensis, known locally as cina, is a member of the subtribe Stenocereinae, which is closely related to the subtribe Pachycereinae (5). $P$. opuntiae var. thermotolerans is found in the latter subtribe of cacti. The reasons for its absence from the subtribe Stenocereinae are still under investigation. $P$. opuntiae var. opuntiae occurs in a different cactus tribe (the Opuntiaeae), which could explain its sensitivity to the inhibitory compound(s) found in the cina powder. This inhibitory effect is only exhibited at the low temperature $\left(24^{\circ} \mathrm{C}\right)$, whereas inhibition is eliminated at a higher temperature $\left(30^{\circ} \mathrm{C}\right)$. The consistent response for all strains within each variety gives additional support for establishing the two varieties.

$P$. opuntiae is similar in some respects to Pichia heedii and $P$. amethionina (Table 3). The only differences presently recognized among the three species and their varieties are listed in Table 3. P. opuntiae differs from all other Pichia species thus far isolated from cactus rots by its strong assimilation of salicin. Despite their many other similarities, mixes of opposite mating types of $P$. opuntiae with mating types of $P$. heedii and $P$. amethionina do not produce zygotes. Therefore, these three species represent true biological species. Utilizing the raw data (i.e., strain means) from the descriptions of $P$. heedii (11) and $P$. amethionina (16), the mean moles percent $\mathrm{G}+\mathrm{C}$ of the nuclear genomes for these species can be compared with the data, given in Tables 2 and 3, for the two varieties of $P$. opuntiae. An analysis of variance of these data indicates a significant $(\mathrm{F}=20.2[4,18] ; P=0.005)$ difference among group (species or variety) means. Table 3 indicates those means which are statistically the same and those which are different. This comparison serves to indicate the range of variation in $\mathrm{G}+\mathrm{C}$ content (standard deviation $=0.05$ to $0.32 \mathrm{~mol} \%$ ) present in heterothallic yeast species. Whether wider variation exists has yet to be determined. We feel experiments on the degree of DNA-DNA homology among the three physiologically and ecologically similar yet sexually non-interfertile species would be enlightening.

Another interesting trend observed for the two varieties of $P$. opuntiae, which is also apparent for the common cactus yeast $P$. cactophila (15), is the small yet statistically significant decrease in the $\mathrm{G}+\mathrm{C}$ content of the nuclear DNA for strains found within the Sonoran Desert as compared with strains recovered outside of the Sonoran Desert. In both cases the decrease in the $\mathrm{G}+\mathrm{C}$ content may represent a 
TABLE 4. Correlation of physiological and host plant shifts for three similar cactus-associated yeasts

\begin{tabular}{|c|c|c|c|c|c|c|}
\hline Yeast species & $\begin{array}{r}\text { Physiolo } \\
\text { shift }\end{array}$ & gical & & & Host shift & $\begin{array}{l}\text { Inter- } \\
\text { fertility } \\
\text { of } \\
\text { physio- }\end{array}$ \\
\hline $\begin{array}{l}\text { P. opuntiae var. opuntiae } \rightarrow \\
\text { P. opuntiae var. thermoto- } \\
\text { lerans }\end{array}$ & $\begin{array}{l}\text { Cellobiose } \\
\text { Citrate } \\
\text { Growth at } 37^{\circ} \mathrm{C} \\
\text { Cina resistance }\end{array}$ & $\begin{array}{l}1^{a} \\
+ \\
- \\
-\end{array}$ & $\rightarrow$ & $\begin{array}{l}+ \\
- \\
+ \\
+\end{array}$ & $\begin{array}{l}\text { Tribe Opuntiaeae } \rightarrow \text { (subtribe } \\
\text { Opuntiinae) } \\
\text { Tribe Pachycereeae (subtribe } \\
\text { Pachycereinae) }\end{array}$ & Poor \\
\hline $\begin{array}{l}\text { P. amethionina var. pachycer. } \\
\text { eana } \rightarrow \text { P. amethionina var. } \\
\text { amethionina }\end{array}$ & $\begin{array}{l}\text { Mannitol } \\
\text { Cina resistance }\end{array}$ & $\begin{array}{l}+ \\
-\end{array}$ & $\rightarrow$ & $\overline{+}$ & $\begin{array}{l}\text { Subtribe: Pachycereinae } \rightarrow \\
\text { Subtribe: Stenocereinae }\end{array}$ & Fair \\
\hline P. heedii & Citrate & + & $\rightarrow$ & - & $\begin{array}{l}\text { Within subtribe Pachycer- } \\
\text { einae, Senita } \rightarrow \text { Saguaro }\end{array}$ & Good \\
\hline
\end{tabular}

${ }^{a}$ l, Latent.

similar adaptive response to the evolutionary pressures experienced in the Sonoran Desert.

One outstanding feature of the three heterothallic cactus-specific yeasts $P$. opuntiae, $P$. amethionina, and $P$. heedii is the correlation between the change in physiological types and the switching of host plants. $P$. heedii has been recovered in both Carnegia gigantea (Engelm.) Britt. et Rose (saguaro) and Lophocereus schottii (Engelm.) Britt. et Rose (senita). However, citrate-positive strains of $P$. heedii have only been found in senita cactus, whereas strains negative for citrate utilization are found in decaying saguaro. This difference in physiology has been shown to be under the control of a single genetic locus (11).

$P$. amethionina shows a similar physiological shift when it switches host plants. Strains occurring predominantly in cacti of the subtribe $\mathrm{Pa}$ chycereinae are in general positive for their ability to assimilate mannitol, whereas strains recovered from cacti of a related subtribe (Stenocereinae) are negative for their ability to utilize mannitol. Once again the difference in physiology accompanying the shift of host plant is under the control of a single genetic locus (16).

$P$. opuntiae shows a greater shift in physiology when strains recovered from Opuntia and cereoid cacti are compared. In this case cellobiose, citrate, and mannitol assimilation, as well as maximum ternperature of growth, is involved (Table 4). We have not completed the genetic analysis of the physiologically variable characters in $P$. opuntiae due to poor sporulation in the intervarietal crosses. Table 4 summarizes the above discussion for the three species and illustrates that the degree of interfertility among different physiological strains is positively correlated with the degree of relationship of the host plants involved in the shifts. One can view the three yeasts as representative of three distinct phases in the process of speciation: (i) $P$. heedii has diverged into two closely related cacti of the same subtribe (Pachycereinae) and probably represents the beginning of "host race" formation; (ii) P. amethionina has diverged into two related subtribes of cacti (Pachycereinae and Stenocereinae) and represents the end product of "host race" formation, and thus we call them varieties; (iii) $P$. opuntiae has diverged into two different tribes of cacti (Opuntiaeae and Pachycereeae) and could represent the beginning of the speciation process or species in statu nascendi.

\section{ACKNOWLEDGMENTS}

We thank Joanne Tredick for the determination of the DNA base compositions. We greatly appreciate assistance with field collections in Baja California by Alexander Russell, Jr., Jean S. Russell, and William R. Johnson and in Australia by Greg Toll and Peter East. A gift of Zymolyase from the Research Laboratories of Kirin Breweries Ltd., Takasaki, Japan, is gratefully acknowledged.

This research was supported by Public Health Service grant GM-16307-08 from the National Institute of General Medical Sciences to H. J. P., by a grant from the National Science Foundation to W. B. Heed and H. W. Kircher (DEB 74-19148A03), and by a grant from the Australian Research Grants Committee (D $175 / 15866$ ) to J. S. F. B.

\section{REPRINT REQUESTS}

Address reprint requests to: $H$. J. Phaff, Department of Food Science and Technology, University of California, Davis, CA 95616 .

\section{LITERATURE CITED}

1. Barker, J. S. F. 1977. Cactus-breeding Drosophila-a system for the measurement of natural selection. Proceedings of the symposium, Measuring Selection in Natural Populations, Denmark, May, 1976. Lect. Notes Biomath. 19:403-430.

2. Barker, J. S. F., and J. C. Mulley. 1976. Isozyme variation in natural populations of Drosophila buzzatii. Evolution 30:213-233.

3. Bernardi, G., M. Foures, G. Piperno, and P. P. Slon- 
imski. 1970. Mitochondrial DNAs from respiratory-sufficient and cytoplasmic respiratory-deficient mutants of yeast. J. Mol. Biol. 48:23-42.

4. Fowell, R. R. 1969. Sporulation and hybridization of yeasts, p. 363. In A. H. Rose and J. S. Harrison (ed.), The yeasts, vol. 1. Academic Press Inc., New York.

5. Gibson, A. C., and K. E. Horak. 1978. Systematic anatomy and phylogeny of Mexican columnar cacti. Ann. Mo. Bot. Gard. 65:999.

6. Heed, W. B., W. T. Starmer, M. Miranda, M. W. Miller, and H. J. Phaff. 1976. An analysis of the yeast flora associated with cactiphilic Drosophila and their host plants in the Sonoran Desert and its relation to temperate and tropical associations. Ecology 57:151160.

7. Marmur, J. 1961. A procedure for the isolation of DNA from microorganisms. J. Mol. Biol. 3:208-218.

8. Meyer, S. A., and H. J. Phaff. 1970. Taxonomic significance of the DNA base composition in yeast, p. 1-29. In D. G. Ahearn (ed.), Recent trends in yeast research, Spectrum vol. 1. Georgia State University, Atlanta.

9. Mulley, J. C., and J. S. F. Barker. 1977. The occurrence and distribution of Drosophila aldrichi in Australia. Drosophila Inf. Serv. 52:151-152.

10. Nakase, T., and K. Komagata. 1970. Significance of DNA base composition in the classification of the yeast genus Pichia. J. Gen. Appl. Microbiol. 16:511-521.

11. Phaff, H. J., W. T. Starmer, Mary Miranda, and M. W. Miller. 1978. Pichia heedii, a new species of yeast indigenous to necrotic cacti in the North American
Sonoran Desert. Int. J. Syst. Bacteriol. 28:326-331.

12. Price, C. W., G. B. Fuson, and H. J. Phaff. 1978. Genome comparison in yeast systematics: delimitation of species within the genera Schwanniomyces, Saccharomyces, Debaryomyces, and Pichia. Microbiol. Rev. 42:161-193.

13. Schildkraut, C. L., J. Marmur, and P. Doty. 1962. Determination of the base composition of deoxyribonucleic acid from its buoyant density in $\mathrm{CsCl}$. J. Mol. Biol. 4:430-433.

14. Starmer, W. T., W. B. Heed, M. Miranda, M. W. Miller, and H. J. Phaff. 1976. The ecology of yeast flora associated with cactiphilic Drosophila and their host plants in the Sonoran desert. Microb. Ecol. 3:1130 .

15. Starmer, W. T., H. J. Phaff, Mary Miranda, and M. W. Miller. 1978. Pichia cactophila, a new species of yeast found in decaying tissue of cacti. Int. J. Syst. Bacteriol. 28:318-325.

16. Starmer, W. T., H. J. Phaff, Mary Miranda, and M. W. Miller. 1978. Pichia amethionina, a new heterothallic yeast associated with the decaying stems of cereoid cacti. Int. J. Syst. Bacteriol. 28:433-441.

17. Szybalski, W. 1969. Use of cesium sulfate for equilibrium density gradient centrifugation. Methods Enzymol. 12: $330-360$.

18. van der Walt, J. P. 1970. Criteria and methods used in classification, p. 34-113. In J. Lodder (ed.), The yeastsa taxonomic study. North-Holland Publishing Co., Amsterdam. 